\title{
The impact of international scientists, engineers, and students on U.S. research outputs and global competitiveness
}

\author{
Sarah M. Rovito*1 ${ }^{\star 1}$ Divyansh Kaushik ${ }^{2}$, and Surya D. Aggarwal ${ }^{3}$ \\ Edited by Julie Stahlhut and Yana Petri
}

\section{HIGHLIGHTS}

- The U.S. has long been a destination of choice for international researchers, who have directly contributed to the nation's sustained leadership in science and engineering as evidenced by a case study of MIT faculty.

- Countries including China, Canada, the United Kingdom, and Australia have implemented programs to attract and retain scientific talent, while the U.S. risks losing its comparative advantage.

- Intentional, strategic action is needed for the U.S. to continue to attract and retain scientific talent and to overcome outmoded visa laws and anti-immigrant rhetoric leading researchers to relocate elsewhere.

International scientists, engineers, and students have made and continue to make significant contributions to the U.S.'s science and engineering research enterprise. This source of talent is a comparative advantage for the U.S. and is critical for keeping the nation at the leading edge of discovery and knowledge. This paper quantifies and reaffirms the impact of international scientists and scholars, who serve as a vital source of talent fueling American ingenuity, innovation, and leadership. Bolstering measures to attract and retain top students from across the globe and fostering a culture where immigrants are welcome and can thrive is imperative for the continued success of the U.S.'s society and economy.

nternational scientists and engineers from across the globe impacted and advanced the U.S.'s health, economic prosperity, and national security throughout the 20th Century. Top scientists including Albert Einstein and Enrico Fermi emigrated to the U.S. in the lead-up to World War II to escape new racial laws and possible persecution in Germany

\footnotetext{
${ }^{1}$ Rovito Ventures LLC, Silver Spring, MD

${ }^{2}$ School of Computer Science, Carnegie Mellon University, Pittsburgh, PA

${ }^{3}$ Department of Microbiology, NYU Langone Health, New York, NY

*Email: smr32@alum.mit.edu
}

SMR declares no conflict of interest; DK and SDA are international scientists at U.S. universities.

(C) 2021 The Author(s) and Italy, respectively [1]. The Institute for Advanced Study at Princeton University assisted Einstein and other leading scientists with finding positions in the U.S., whereas Fermi joined Columbia University [2]. These foreign scientists were instrumental to the success of the Manhattan Project and ultimately revolutionized American innovation [3].

Immigrant scientists and engineers made substantial contributions to the Space Race in the 1960s, assisting with the Apollo missions and leading the U.S. to the Moon [4]. More recently, scientists born outside of the U.S. played key roles in the development of the Pfizer-BioNTech and Moderna mRNA COVID-19 vaccines [5]. Furthermore, immigrants have received an outsize proportion of Nobel Prizes awarded to Americans, including $37 \%$ of the Nobel Prizes received by U.S.-based researchers in chemistry, medicine, and physics since 2000, and start new businesses at a rate double that of American citizens at birth $[6,7]$.

\section{Background and Current Problems}

Anti-immigrant rhetoric and policies, outmoded visa laws, and increasing competition for talent may be causing many scientists and engineers to look beyond the U.S. for education and employment [8]. As we see an increased focus on immigration reform and the need for attracting-and retaining-global talent to the U.S., it is important to frame this need within a global context. Below, we compare policies enacted by China, Canada, and the United Kingdom with the intent of achieving similar objectives.

China China implemented the Thousand Talents Plan, a key component of the nation's quest to become a global scientific leader, in 2008. Scientists and researchers from across the world have since committed to participate in the talent recruitment program and contributed to China's skyrocketing technology development and intellectual property portfolio. China overtook the U.S. with respect to the number of international patents filed for the first time in 2019, with 58,990 applications submitted compared to 57,840 by the U.S. [9]. The Thousand Talents Plan was declared a threat to American interests by a U.S. Senate Committee in 2019, which identified it as one of 200 talent recruitment programs run by the Chinese government that has recruited over 60,000 
scientists since 2008 [10].

In addition to this, China has embarked on an aggressive effort to recruit international students. The number of English-speaking African students in China exceeded the number of students from this demographic in both the U.S. and UK in 2014 [11]. It is not just the increase in the number of African students studying in China that is worth noting, but also the rate at which this number has increased. While fewer than 2,000 African students were enrolled at Chinese universities in 2003, this number was 81,562 as of 2019 [12]. Then-Senator John F. Kennedy remarked in 1959 that "Opening our universities and college doors to several times as many African students as now come over-this would be an investment which would be repaid to this country many times over in increased goodwill, trade and national security" [13]. But it is China, and not the U.S., that appears to be winning this race for untapped talent.

Canada Canada is steadily rising in the ranks and emerging as a top destination for global scientific talent. In 2015, Canada established Express Entry, an immigration program intended to fast-track applications of highly-skilled immigrants, among others, into the country [14]. Since then, Express Entry has become an attractive offering for international scientists and engineers working in the U.S. who face decades-long backlogs in the employment-based green card system [15] (Figure 1). This is in line with the Canadian approach of proactively recruiting immigrants, evident through a long history of the Canadian government and Canadian companies putting up billboards in Silicon Valley $[16,17]$.

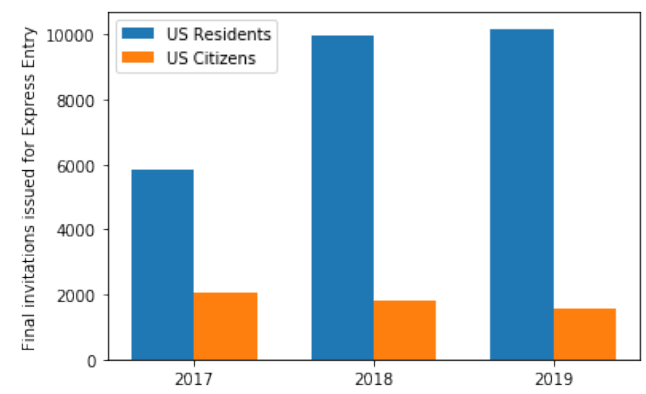

Figure 1: Final invitations issued by the Canadian government to Express Entry applicants [18].

Canada observed an increase in high-skilled immigration from the U.S. from 2017, primarily due to the increase in non-citizen U.S. residents migrating to Canada. Between 2017 and 2019, Canada's Express Entry program saw an increase of $75 \%$ in successful applications from the U.S. and an increase of at least $128 \%$ in successful submissions from U.S. non-citizens [18]. The number of non-citizen U.S. residents receiving invitations to apply for Canadian permanent residence through Express Entry during this same period is over 20,000 , and more than $80 \%$ of these individuals received invitations within 6 months of applying [18].

United Kingdom Following Brexit, the United Kingdom implemented reforms to improve the efficacy of its immigration system. This included excluding doctors and nurses from being counted under a visa cap, an action which opened slots within the cap for additional highly-skilled occupations including engineers and IT professionals. Beyond this, the UK Parliament issued a report titled, "An Immigration System that works for Science and Innovation" in 2018. The report accurately points out, "The science and innovation community is not homogeneous; people have different types and levels of skill, and are at different stages in their career, all of which will have an impact on their mobility. Several submissions set out the skills, and career stages, that an immigration system needs to support if it is to work effectively for science and innovation" [19]. One of the recommendations this report gave to the government was to loosen the requirements to qualify for the Tier-1 (exceptional talent) visa.

The government announced in January 2020 that it was replacing the Tier-1 visa with the Global Talent Visa to attract scientists, researchers, and mathematicians from around the world [20]. There is no cap on the number of visas issued in a year, further signaling the UK's appetite for supporting talented individuals. UK Research and Innovation (UKRI) decided to endorse scientists and researchers for this visa, an unprecedented move. These visa changes went into effect in February 2020 and are aimed at providing researchers and their families a 3-5 year pathway to permanent residency in the UK.

With these developments in and commitments by China, Canada, the UK, and elsewhere, the U.S. is facing a changed, increasingly competitive landscape for top international talent. The U.S. does not currently have a strategic program to compete with the likes of the Thousand Talents Plan, Express Entry, or Global Talent Visa. It is well known that backlogs in the employment-based green card system are hurting the U.S., with lengthy wait times and arbitrary caps, especially in fields that are critical to stimulating economic growth [21]. Furthermore, the number of green cards allotted each year has not changed since the 1990s, even with significant economic growth. Policymakers have considered, and continue to consider, measures for increasing the number of green cards and prioritizing applicants with STEM Ph.D.s as evidenced by the U.S. Citizenship Act of 2021 (1), the Startup Act (2), Keep STEM Talent Act (3), and the Fairness for High-Skilled Immigrants Act of 2019 (4) among other legislation. U.S. Agency for International Development (USAID) Administrator and former U.S. Ambassador to the United Nations Samantha Power remarks that "lowering the visa hurdles for study in the United States while creating better, more accessible pathways for international students to work in the United States after graduation can pay both shortand long-term dividends in expanding U.S. influence" [22].

\section{Contributions of International Scientists to MIT's Research Output}

To study the contributions of international scientists to the research output of U.S. universities, we analyze data from the Massachusetts Institute of Technology (MIT) as a case study. Faculty, staff, and students come to MIT from around 


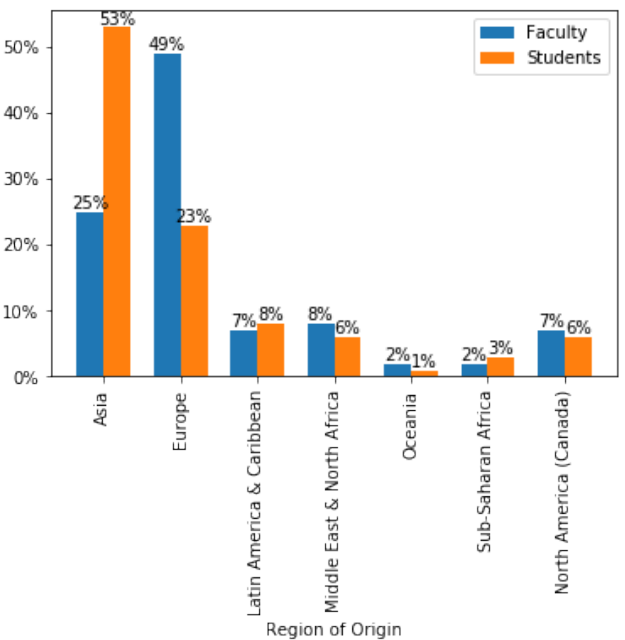

Figure 2: MIT foreign-born faculty and international students by region of origin.

the world for research, teaching, and other collaborative purposes [23]. During the 2018-2019 academic year, over 2,000 international scholars (visiting researchers, professors, and lecturers) were affiliated with the MIT community [24]. These individuals hail from over 90 countries and conduct scholarly activities in over 70 MIT courses and laboratories [24]. Furthermore, 3,331 international students were enrolled in degree programs at MIT during the 2019-2020 academic year-458 undergraduate students (10\%) and 2,873 graduate students (41\%), along with an additional 644 exchange, visiting, cross-registered, and special international students on campus [25]. MIT President L. Rafael Reif is an immigrant himself and a leading voice on international scholars' contributions to American innovation and competitiveness [26].

We obtained and combined two data sets in support of this analysis: one from the MIT Office of the Provost containing faculty region of origin at birth, and one from higher education business intelligence firm Academic Analytics through special research-use permission by the Academic Analytics Research Center (AARC) containing faculty bibliometric data (research outputs; database version AAD2019) [27]. The former data set mapped country of birth to region of origin at birth for each faculty member according to the Council of Graduate Schools' International Graduate Admissions Survey guidelines [28].

The final data set contained information for 1125 tenured and tenure-track faculty from all MIT schools and departments from $2015-2019$. $43 \%$ or 502 of the 1125 faculty members were born outside of the U.S., with the largest group hailing from Europe (244) and followed by Asia (128), the Middle East \& North Africa (40), Latin America \& the Caribbean (35), North America (34), Oceania (12), and Sub-Saharan Africa (9). Figure 2 compares the region of origin of MIT faculty from the data set with MIT 2019-2020 international student data [25].

Further exploration of the final data set reveals the impact of foreign-born faculty on MIT's research outputs. These

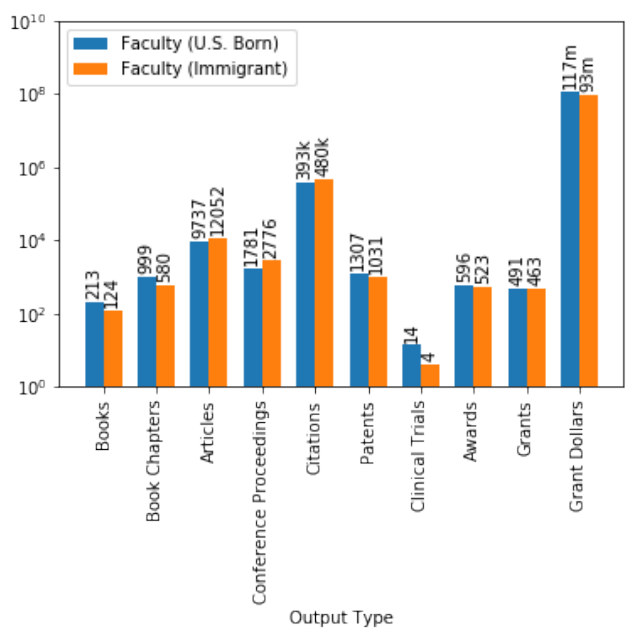

Figure 3: Research outputs of U.S.-born and foreign-born MIT tenured and tenure-track faculty from 2015-2019.

data are consistent with past findings showing the increased productivity of foreign-born scientists and engineers with respect to bibliometric outputs [29]-[33]. While foreign-born faculty make up less than half $(44.6 \%)$ of the total MIT faculty, they publish over half of all journal articles and conference papers and also are cited more than their U.S.-born colleagues-who publish more books, book chapters, and hold more patents. The two groups are nearly equal in awards and grants (Figure 3). Using 2019 as the base year, the median years since obtaining a Ph.D. for domestic-born faculty is 25 years while that for those born outside the U.S. is 18 years, suggesting that these numbers would be even higher for international faculty when adjusted for year of graduation from Ph.D. MIT also boasts of a considerable population of international graduate students and postdoctoral researchers; these trainees conduct research in teams led by both domestic and foreign-born faculty members [34]-[36].

This analysis does not control for research disciplines, which could play a role in determining a researcher's preferred mode of publication and the number of citations they receive and would require a more nuanced analysis. Even though the current analysis is not exhaustive, it seeks to capture the contributions of foreign-born faculty, students, and researchers to the MIT community at an aggregate level. There is evidence showing that racial diversity on campus uniquely contributes to students' learning and educational experiences; by recruiting international scientists, universities like MIT are able to not only improve their research output but also reap educational benefits from top domestic and international talent learning together [26, 37]

\section{A Global Race For Talent}

International scientists are key to scientific breakthroughs coming out of US universities as evidenced by our previous analysis. Hence, it is essential to put these findings into broader context and better understand how various factors influence where scientists and students wish to migrate. Although it is difficult to ascertain and perhaps 
unreasonable to assume that one specific factor solely influences international scientists' decisions on where to relocate to perform research or students' decision on where to pursue education, it seems intuitive that the domestic policies and rhetoric targeting immigrants would have a large impact on their choice. The emerging body of evidence on this topic suggests that rhetoric and visa concerns may have deterred foreign students from pursuing education and research opportunities in the U.S., with many instead opting to head to other countries such as the UK, Australia, and Canada [38]-[40].

In 2015, Business Roundtable analyzed the policies implemented by various countries to compare how the U.S. stacked up against other advanced economies in the race for global talent [41]. The immigration policies of each nation were broken down into key categories and rated on a scale of 1 (least favorable) to 5 (most favorable) with respect to their favorability to growth. Business Roundtable found that countries imposing fewer immigration-related restrictions received higher scores in various categories pertaining to business or economics. At the end, the countries were ranked based on the average of all scores received in various categories. Of the 10 countries that were analyzed in this report, the U.S. ranked 9th, ahead only of Japan-a country that has historically imposed severe immigration restrictions.

Many industrialized countries have made updates to their immigration laws since 2015, however, as evidenced by Canada's implementation of the Express Entry visa program in 2015 and a Startup Visa in 2018, and over 400 changes to U.S. immigration policy implemented between 2017 and 2020 [42]. Thus, it is essential to attempt to better understand the trends of talent flow as it relates to scientific research. To do this, we focus on the talent flows of graduate international students in STEM fields wherever possible, but fall back to graduate international students, or international students if data are not available. Additionally, most countries have a special visa category for international students, unlike faculty or postdoctoral researchers who often apply in the same visa categories as industry professionals. Thus, we analyze trends of international students enrolling at institutions of higher education in four countries-the U.S., the UK, Australia, and Canada-over a period of at least 10 years using the number of student visas issued each year as a proxy for new international student enrollments. ${ }^{1}$ The purpose of this analysis is not to make a causal claim but rather to analyze the enrollment trends themselves. This can help us understand whether international students looking to pursue graduate education might be responsive to more immigrant-friendly rhetoric [43].

For data for each country, we first fit a linear regression model on data up until 2016 and project new enrollment figures for years 2017 and later based on respective regression models. The key idea here is that if the only change before and after 2016 was the increased anti-immigrant

${ }^{1}$ In most cases, we could not find reliable data for a longer time period. rhetoric and pro-immigrant policies in other countries, we might observe enrollment trends to track these developments. A limitation of this approach is that it does not account for all possible factors that might influence a foreign student's choice of institution and country. Thus, it is conceivable that our estimates could partly reflect unobservable systemic differences between international students applying to various programs up until 2016 and after 2016

United States Our analysis suggests that the prevailing anti-immigrant rhetoric and policies proposed during the 2016 presidential election likely led to a significant drop in new international graduate enrollments at U.S. universities. While U.S. universities saw these numbers drop from 126,516 in 2015 (the highest observed) to 120,332 in 2019, estimating new enrollments based on previous numbers, we project that the U.S. might have attained 146,410 new international graduate enrollments in 2019 (Figure 4) if previous trends remained unchanged.

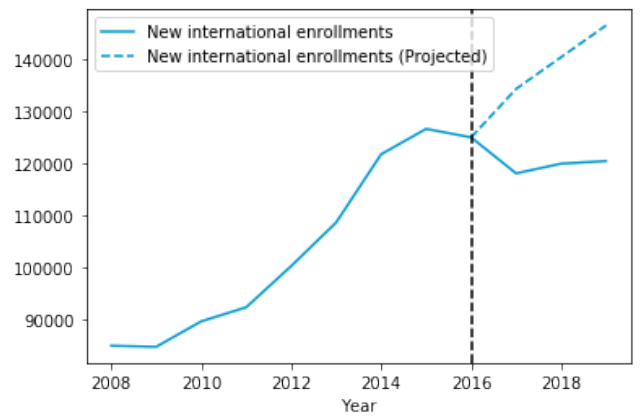

Figure 4: New international graduate students enrolling at U.S. universities. Solid lines indicate the observed numbers; the dotted line from 2016 onward represents the projected enrollments based on observed data for student enrollments until 2016 [44].

Australia In contrast, Australia saw a substantial increase in visas issued to new international students (undergraduate and graduate) post-2016 (Figure 5). While our projected estimates suggest that only about 193,000 new international students might have received a student visa in 2018, the actual number was 240,419 , which amounts to an increase of 53,496 visas in just two years. In comparison, the increase in new student visas in the two years leading up to 2016 was only 15,462 . Our estimates suggest that Australia could have seen more international postgraduate researchers than the observed numbers. However, it is important to note that Australia started to see a drop in these numbers starting in 2013 along with an immediate increase following 2016, reaching an all-time high of 12,833 new visas issued in 2018.

United Kingdom While the number of non-UK students enrolling at UK universities was stagnant between 2010 and 2016, this number increased dramatically in the following years (Figure 6a). We estimate that following existing trends, UK universities might have seen slightly less than 270,000 new enrollments from all non-UK countries compared to the actual number of 319,825 new students-a difference of approximately 50,000 new students. As immigration changes made by then-Home Secretary Theresa May in 2012, which 


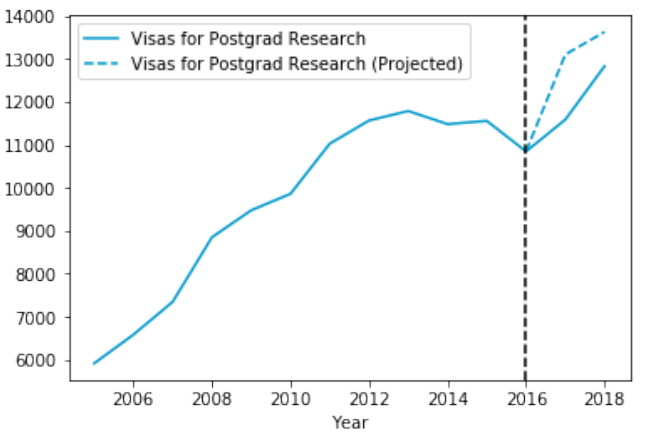

(a) Postgraduate Researchers

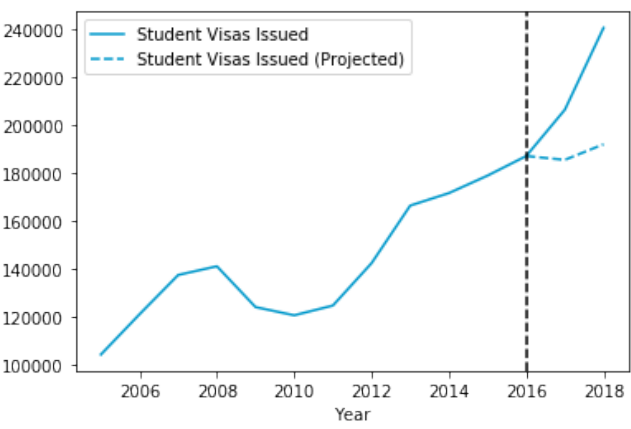

(b) UG and Graduate students

Figure 5: Solid lines indicate number of visas issued by Australia from 2004-2018. Dotted lines show the projected numbers post 2016 [45].

closed the Tier 1 Post Study Work Route and forced international students to leave the UK four months after finishing their degrees, were not reversed until 2019 [46, 47], it is likely that the immediate gains in new international students were at least partly influenced by anti-immigrant rhetoric in the U.S., which made the UK an attractive destination for foreign students even while the 2012 migration policy was still in place.

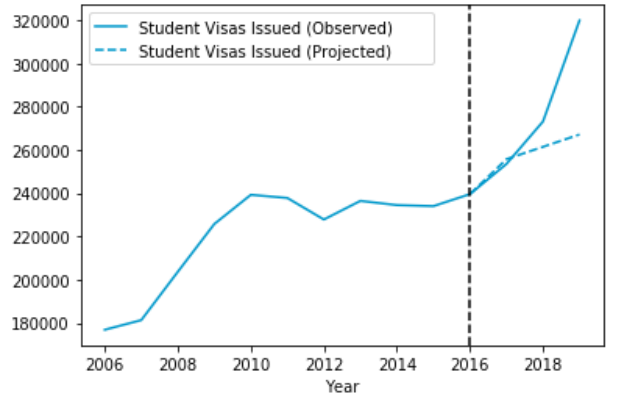

(a) All programs

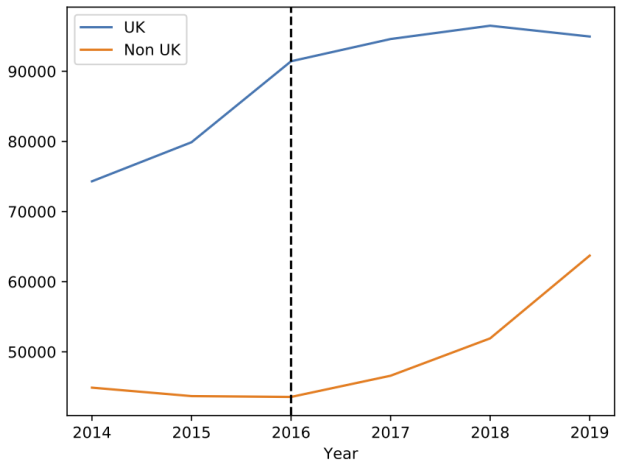

(b) STEM fields

Figure 6: New international students and researchers enrolling at UK universities (observed and projections) $[48,49]$.

In 2014, the UK agencies also started collecting data on students enrolling in STEM degrees (Figure 6b). We observe that the number of new international graduate students enrolling in STEM programs at UK universities decreased between 2014 (44,895 students) and 2016 (43,570 students) but saw an immediate increase following 2016 , leading up to an all-time high of 63,720 new students in 2019.
Canada We observe an almost linear trend in student visas issued by Canada for postsecondary education (undergraduate and graduate enrollees in all academic disciplines) from 2008 to 2015, growing at an average rate of approximately 18,000 visas each year (Figures $7 \mathrm{a}$ and $7 \mathrm{~b}$ ). In 2016, Canada issued 46,345 more visas than in 2015. The number of new visas issued grew rapidly thereafter, at an average rate of over 47,000 visas each year. We believe that if Canada continued to follow this trend, it might have issued slightly over 360,000 student visas to students coming for postsecondary education compared to the actual number of 497,450 new students-a difference of approximately 140,000 new students. We also observe a similar trend in international students coming to pursue graduate STEM programs in Canada. While the rate of increase in international student enrollments is almost constant until 2016, there is a considerable increase in the rate after 2016. It is possible that absent any policy and rhetoric changes, slightly under 31,000 international students would have been enrolled in Canadian universities to pursue graduate studies in STEM fields compared to the observed number of almost 33,000 .

It is worth noting that during this period the number of international students pursuing postsecondary studies abroad has increased consistently. Data from Project Atlas suggest that between 2014 and 2019, there was over an 18\% increase in the number of students going abroad to undertake higher education [51]. Thus, while the supply of international students has only been increasing, it is the demand for an American education that has taken a hit.

We acknowledge that the lack of more observable variables limits the precision of this analysis. However, paired with existing literature on how the anti-immigrant posture of various countries leads to a decline in their respective immigrant populations, these findings-evidenced by a decrease in international student enrollments in the U.S. post-2016 and an increase observed in similar industrialized nations that might have been seen as relatively more immigrant-friendly-suggest that both rhetoric and policies influence the choices of international students [52]-[54].

\section{Findings}

MIT Science Policy Review | August 30, 2021 | vol. 2 | pg. 19 


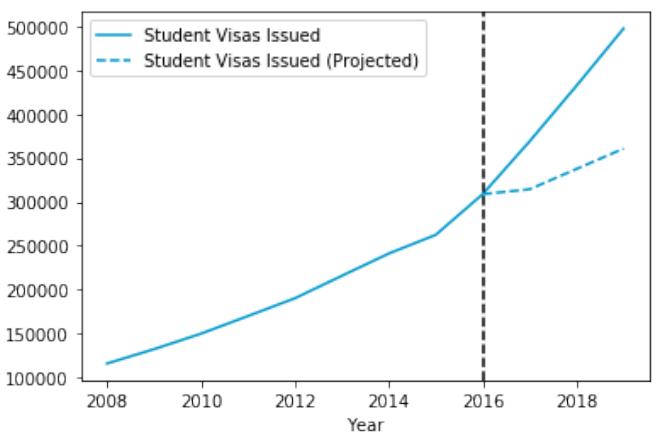

(a) Postsecondary programs

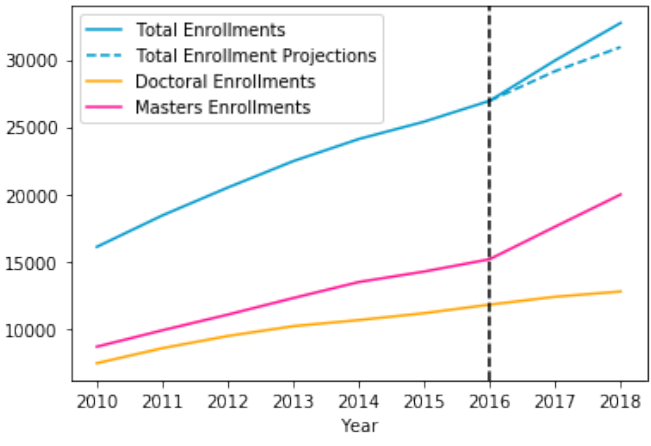

(b) STEM graduate programs

Figure 7: Student visas issued by Canada (observed and projections) $[18,50]$.

The ability to recruit global talent is a key factor that has contributed to US leadership in science and research. This talent has been vital for the development of US science and responsible for numerous discoveries and innovations that have improved quality of life. Since 2000, there has been an increase in the number of programs in the US offering STEM education. While the number of domestic-born students pursuing these programs has increased, this has been outpaced by the growth of international students enrolled in these programs. In 2017, international students formed nearly half of first-year graduate students enrolled in full-time natural science and engineering programs. More than $40 \%$ of the students pursuing STEM Ph.D.s are international students, and this number is closer to $60 \%$ in certain fields such as computer science. Furthermore, $49 \%$ of U.S.-trained science and engineering postdoctoral researchers were born overseas, and the corresponding number at the faculty level was $29 \%$ [55].

Membership in professional organizations such as the National Academy of Sciences (NAS) and National Academy of Engineering (NAE) is one of the highest professional honors and a recognition of members' outstanding achievements during their careers. International scientists and engineers were found to be disproportionately represented in the membership of both the NAS and NAE [56]. It would not be an overstatement to suggest that international researchers are indispensable to U.S. science. A previous study concluded that foreign-born researchers make disproportionate contributions to American science and engineering, perhaps cementing this claim $[56,57]$. If it were not for international students, both undergraduate majors and graduate programs could not be maintained at the current levels [58]. In fact, some graduate-level programs would not be viable and subsequently would be unavailable to domestic students without international enrollments [58]. This would have negative consequences for not just the educational mission of U.S. institutions, but would also dramatically lower their research outputs.

The Bureau of Labor Statistics projected that between 2016 and 2026, the U.S. would need approximately 5.179 million scientists and engineers, including 3.477 million in computer occupations and 1.265 million in engineering occupations [59]. International researchers are critical in meeting this demand as for the most part, they do not compete with domestic researchers but rather complement their work [60]-[64]. Various economists have found that a greater proportion of scientists and engineers in the U.S. workforce can account for half of U.S. growth in total factor productivity in decades [62], and that highly-skilled immigrants displace very few American-born workers while boosting innovation and productivity [65]. In addition, a National Academies report found that the presence of immigrant workers in the labor market contributed $\$ 2$ trillion to the U.S. GDP in 2016, and that a decline in the immigrant workforce would cause the U.S. GDP, and perhaps per-capita GDP, to shrink as well [66]. It has been estimated that a $10 \%$ increase in international graduate students leads to a $4.5 \%$ increase in patent applications [67]. Economists also have determined that patents per capita are boosted between $9 \%$ and $18 \%$ given a $1 \%$ increase of immigrant college graduates in the population, and that about a fifth of new patents filed during 1940-2000 were on account of the increasing share of immigrant college graduates as part of the population [68].

In 2013, the Congressional Budget Office (CBO) also estimated that passing a comprehensive immigration reform, the wages of all U.S. workers would decrease by $0.1 \%$ by 2023 but ultimately increase by $0.5 \%$ by 2033 on account of economic growth [69]. Initially, there would be an influx of new workers that would effectively spread capital a bit thinner and lead to a small decrease in the average wage. However, the resulting increase in productivity would boost return on investment and then increase wages across the board to levels higher than before. The CBO also identified that the U.S. GDP would increase an additional $3.3 \%$ by 2023 and $5.3 \%$ by 2033 when taking into consideration the broader macroeconomic effects associated with immigration reform. This economic growth would lead to job creation, as unemployment would not increase as immigration reform bolstered the domestic labor force. [70].

International students not only help the U.S. maintain its edge in the global research and innovation enterprise but also serve as a critical economic asset. According to 
the U.S. Department of Commerce, international students contributed over $\$ 44$ billion to the American economy during the 2018-2019 academic year [71]. This spending results in over 458,000 American jobs being created and supported by international students. This translates to three American jobs being created and supported for every seven international students in the U.S.

Growth in the international student population leads to an inflow of valuable tuition dollars to American universities, providing resources to hire more faculty, increase enrollments of domestic students, upgrade existing infrastructure, and expand their physical footprint. In the context of reduced state spending on public colleges and universities, the importance of these tuition dollars in supporting American higher education cannot be overstated. A decade since the Great Recession of 2008, inflation-adjusted state funding for public two- and four-year colleges in 2017 was approximately $\$ 9$ billion below 2008 levels [72]. Despite recent increases in funding to higher education, states have only recovered about two-thirds of lost funding over the years [73]. These funding cuts have had major consequences for the higher education mission of these public universities, which have been forced to increase tuition or cut back on educational offerings in order to make ends meet [72].

A creative approach to weathering this storm has been to increase the recruitment of international students and the associated out-of-state tuition revenue at public universities. The number of new foreign students enrolled at public universities has grown faster than the number enrolled at private institutions, and it has been estimated that a $10 \%$ decline in state appropriations for higher education corresponds to an approximately $12 \%$ growth in international student enrollments at the undergraduate level at public research universities [74, 75].

One example is the University of California, Davis, which had seen a drop in state support to campus revenue by $40 \%$ over the four years since the Recession, resulting in program cuts, staff layoffs, faculty furloughs, and record tuition increases [76,77]. In response to these budget cuts, UC Davis launched its 2020 Initiative with a goal of adding up to 5,000 new undergraduate students by 2020 , with 4,500 of them being out-of-state and international students [78, 79]. From under $4 \%$ in 2009 , the proportion of international undergraduates at UC Davis has risen to slightly over $17 \%$ in 2018-2019 [80,81]. The projected corresponding annual increase in revenue of approximately $\$ 38$ million allowed the university to lay out an ambitious plan seeking to grow its student enrollment (in-state undergraduate and graduate student numbers) and expand its faculty by hiring 300 additional members along with targeting other infrastructure development projects [82, 83].

This highlights how recruiting international students is instrumental for continuing and expanding the education and research missions of U.S. universities. International students help the institutions recruiting them and the domestic students studying alongside them, and they also boost the local and state economy. According to data from NAFSA: Association of International Educators, while international students contributed over $\$ 2.7$ billion to California's economy in 2008 , this number had increased to over $\$ 6.8$ billion in 2018 [84]. The number of international students in California increased only by $74 \%$ during this period.

While the surge of international students during the early 2010s was instrumental in cushioning some U.S. universities and institutions from the adverse impacts of state budget cuts, it is uncertain if this will continue to be the case given enrollment trends and further reductions to state education budgets. Tuition revenue generated by international students is declining, as the number of new international students enrolling at U.S. universities, which grew between seven and ten percent annually between 2012 and 2016, has been decreasing since 2016 [22]. This decline is the result of many disparate factors, but also undoubtedly a function of less welcoming federal policies and anti-immigrant rhetoric. The total international student population in the U.S. dropped by $1.8 \%$ in 2019 over the past year, marking the first time in about fifteen years there was a year-over-year decline in the international student population [85]. Consequently, there was a $4.4 \%$ drop in the amount that international students contributed to the U.S. economy over the past year [84].

COVID-19 has further exacerbated both financial pressures on U.S. universities and declining international enrollment numbers. It has been estimated that the COVID-19 pandemic will cost higher education institutions upwards of $\$ 120$ billion [86]. Overall depressed economic activity due to the pandemic has resulted in some states further reducing their higher education budgets [87]. Furthermore, an Institute of International Education (IIE) survey reported that new and total international student enrollment at U.S. institutions plummeted by a stark $43 \%$ and $16 \%$, respectively, in Fall 2020 [88, 89]. These drops are expected to have long-term negative consequences on the research output of American institutions.

However, the greatest economic impact of international students studying at U.S. colleges and universities takes place after these students have graduated. International faculty and scholars are powerhouse innovators, making profound economic contributions through patents and entrepreneurial activity. Immigrants who are college graduates are twice as likely to hold a patent than a comparable college graduate born in the U.S. [90]. Half of Silicon Valley startups have at least one foreign-born founder, and immigrants, who comprise only $14 \%$ of the total U.S. population, have founded more than half of startups valued at $\$ 1$ billion U.S. dollars or more $[7,90]$.

\section{Conclusion}

Bolstering measures to attract and retain global talent and fostering a culture where immigrants are welcome and can thrive is imperative for the continued success of the US's society and economy [2,90]-[92]. Literature and prior successes strongly suggest that pro-immigrant rhetoric and 
immigration reform designed to meet current needs could play a pivotal role in helping the U.S. win the global race for talent in the coming years. It is vital for the U.S. to intentionally take steps to overcome anti-immigrant rhetoric and policies implemented by the Trump Administration, to expand post-graduation opportunities for international students, and to address outmoded visa laws compelling top talent to look elsewhere. Accordingly, the Biden Administration has committed to expanding the number of highly-skilled visas, reducing visa backlogs, and speeding up the processing of visa and citizenship applications [38]

Reforming immigration policies and instituting a preference for U.S.-educated international students to attain work authorization and remain in the U.S., including exempting doctoral students from green card caps, would help attract more international students to the U.S. [21, 93]-[97]. Refining this to include a streamlined process for awarding green cards to foreign-born STEM doctoral students in particular could impact American innovation and competitiveness and enable startups to attract these individuals [94].

Our analysis suggests that programs like Canada's Express Entry and the United Kingdom's Global Talent Visa that do not place arbitrary caps on scientists and researchers with exceptional abilities or suffer from backlogs and long wait times (unlike the U.S.'s EB-1 and EB-2 programs) are increasingly attracting global talent, often from the U.S. itself $[15,18,98]-[100]$. A new visa program along similar lines could fuel the American research and innovation enterprise in the years to come. Another way to achieve similar benefits would be to exempt U.S. educated STEM Ph.D. students from EB caps altogether, as recommended by the National Security Commission on Artificial Intelligence in 2021 [101]. This also was the subject of various congressional proposals in prior years (1-4).

\section{Acknowledgements}

The authors would like to thank the MIT Office of the Provost and the Academic Analytics Research Center (AARC) for providing the data that made this analysis possible.

\section{Citation}

Rovito, S. M., Kaushik, D., \& Aggarwal, S. D. The impact of international scientists, engineers, and students on U.S. research outputs and global competitiveness. MIT Science Policy Review 2, 15-25 (2021). https: //doi.org/ 10.38105/spr.v079rp249k.

\section{Open Access}

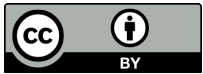

This MIT Science Policy Review article is licensed under a Creative Commons Attribution 4.0 International License, which permits use, sharing, adaptation, distribution and reproduction in any medium or format, as long as you give appropriate credit to the original author(s) and the source, provide a link to the Creative Commons license, and indicate if changes were made. The images or other third party material in this article are included in the article's Creative Commons license, unless indicated otherwise in a credit line to the material. If material is not included in the article's Creative Commons license and your intended use is not permitted by statutory regulation or exceeds the permitted use, you will need to obtain permission directly from the copyright holder. To view a copy of this license, visit http://creativecommons.org/licenses/ by $/ 4.0 /$.

\section{References}

[1] Atomic Heritage Foundation. Scientist refugees and the Manhattan Project. Online: https:// www.atomicheritage.org/article/scientistrefugees-and-manhattan-project.

[2] Watney, C. The egghead gap. The New Atlantis. Online: https://www.thenewatlantis.com/publications/ the-egghead-gap.

[3] Moser, P., Voena, A. \& Waldinger, F. German Jewish émigrés and US invention. American Economic Review 104, 3222-55 (2014). Online: https://www.nber.org/system/files/ working papers/w19962/w19962.pdf.

[4] Steele, J. Book chronicles 218 immigrants who boosted U.S. space program. The University of Alabama in Huntsville News Release. Online: https://www.uah.edu/news/people/ book-chronicles-218-immigrants-who-boostedus-space-program.

[5] Rose, J. If COVID-19 vaccines bring an end to the pandemic, America has immigrants to thank. NPR. Online: https://www.npr.org/2020/12/18/947638959/ifcovid-19-vaccines-bring-an-end-to-thepandemic-america-has-immigrants-to-than.

[6] Anderson, S. Immigrants, Nobel Prizes and the American dream. Forbes. Online: https://www.forbes.com/ sites/stuartanderson/2020/10/14/immigrantsnobel-prizes-and-the-american-dream/?sh= $694 \mathrm{eb} 4 \mathrm{f} 4372 \mathrm{e}$.

[7] Huang, T., Arnold, Z. \& Zwetsloot, R. Most of America's "most promising" Al startups have immigrant founders. Center for Security and Emerging Technology, Georgetown University .

[8] Sofia, M. The international scientists getting pushed out. NPR Short Wave. Online: https://www.npr.org/2020/ 09/01/908356727/the-international-scientistsgetting-pushed-out.

[9] Nebehay, S. In a first, China knocks U.S. from top spot in global patent race. Reuters. Online: https://www.reuters.com/ article/us-usa-china-patents-idUSKBN21P1P9.

[10] Portman, R. Threats to the US research enterprise: China's talent recruitment plans. Online: https: //www.hsgac.senate.gov/imo/media/doc/201911-18\%20PSI20Staff $\% 20$ Report $\% 20-\% 20 \mathrm{China}^{\prime}$ S\% 20Talent:20Recruitment $\% 20$ Plans.pdf.

[11] Breeze, V. \& Moore, N. China has overtaken the US and UK as the top destination for anglophone African students. Quartz Africa. Online: https://qz.com/africa/1017926/chinahas-overtaken-the-us-and-uk-as-the-topdestination-for-anglophone-african-students/.

[12] Ministry of Education, The People's Republic of China. Statistical report on international students in China for 2018. Tech. Rep. Online: http://en.moe.gov.cn/documents/ reports/201904/t20190418_378692.html.

[13] Kennedy, J. F. The United States and Africa: A new policy for a new era. Online: https://www.jfklibrary.org/ archives/other-resources/john-f-kennedyspeeches/new-york-ny-19590628.

[14] The Library of Congress. Points-based and family immigration: Canada. Tech. Rep. Online: https://www.loc.gov/law/ help/points-based-immigration/canada.php.

[15] Desai, K. as told to Rihl, J.. For more than a decade in Pittsburgh, we lived the U.S. immigration nightmare. the pandemic sealed our move to Canada. PublicSource. 
Online: https://www.publicsource.org/pittsburghimmigration-impossible-moved-america-canada/.

[16] O'Brien, M. Canada comes to Silicon Valley to poach high-tech workers struggling with immigration problems. The Mercury News. Online: https://www.mercurynews.com/ 2013/05/16/canada-comes-to-silicon-valleyto-poach-high-tech-workers-struggling-withimmigration-problems/.

[17] Duhatschek, P. Canadian tech group spends $\$ 100 \mathrm{~K}$ on billboards to lure anxious tech workers from U.S. CBC News. Online: https://www.cbc.ca/news/canada/kitchenerwaterloo/tech-billboards-1.5683762.

[18] Immigration, Refugees and Citizenship Canada. Express entry year-end report 2019 (2020). Online: https:// www.canada.ca/content/dam/ircc/migration/ircc/ english/pdf/pub/2019-ee-report-pdfversioneng.pdf.

[19] U.K. House of Commons Science and Technology Committee. An immigration system that works for science and innovation (2018). Online: https://publications.parliament.uk/ pa/cm201719/cmselect/cmsctech/1061/1061.pdf.

[20] U.K. Prime Minister's Office. Boost for UK science with unlimited visa offer to world's brightest and best. GOV.UK Press Release. Online: https: / /www.gov.uk/government/ news/boost-for-uk-science-with-unlimitedvisa-offer-to-worlds-brightest-and-best.

[21] Kahn, S. \& MacGarvie, M. The impact of permanent residency delays for stem PhDs: Who leaves and why. Research Policy 49, 103879 (2020).

[22] Power, S. The can-do power: America's advantage and Biden's chance. Foreign Affairs. Online: https: //www.foreignaffairs.com/articles/unitedstates/2020-11-20/samantha-power-can-do-power.

[23] Massachusetts Institute of Technology. MIT at a glance. MIT Facts. Online: https://web.mit.edu/facts / faqs.html.

[24] Massachusetts Institute of Technology. MIT international scholars office. Online: http://web.mit.edu/scholars/.

[25] Massachusetts Institute of Technology. Enrollments 2019-2020. MIT Facts. Online: https://web.mit.edu/ facts/enrollment.html.

[26] Reif, L. R. I'm the president of M.I.T. America needs foreign students. The New York Times. Online: https://www.nytimes.com/2020/07/14/opinion/ coronavirus-trump-immigration-students.html.

[27] Academic Analytics Research Center. AARC and scholarly research. Online: https://academicanalytics.com/ aarc-scholarly-research/.

[28] Council of Graduate Schools. International graduate admissions survey. Online: https://cgsnet.org/ international-graduate-admissions-survey.

[29] Corley, E. A. \& Sabharwal, M. Foreign-born academic scientists and engineers: producing more and getting less than their us-born peers? Research in Higher Education 48, 909-940 (2007). Online: https://1ink.springer.com/content/ pdf/10.1007/s11162-007-9055-6.pdf.

[30] Levin, S. G. \& Stephan, P. E. Are the foreign born a source of strength for US science? (1999). Online: https://science.sciencemag.org/content/285/ 5431/1213.summary.

[31] Lee, S. Foreign-born scientists in the United States-do they perform differently than native-born scientists? Ph.D. thesis, Georgia Institute of Technology (2004). Online: https:// smartech.gatech.edu/handle/1853/4885.

[32] Kim, D., Wolf-Wendel, L. \& Twombly, S. International faculty: Experiences of academic life and productivity in US universities. The Journal of Higher Education 82, 720-747 (2011). Online: https: //www.tandfonline.com/doi/abs/10.1080/ 00221546.2011 .11777225 ? journal Code=uhe j20.

[33] Mamiseishvili, K. \& Rosser, V. J. International and citizen faculty in the United States: An examination of their productivity at research universities. Research in Higher Education 51, 88-107 (2010). Online: https://link.springer.com/ article/10.1007/s11162-009-9145-8.

[34] Sive, H., Canizares, C. \& Zuber, M. The status of MIT's postdoctoral researchers. MIT Faculty Newsletter XXVI (2013). Online: http://web.mit.edu/fnl/volume/262/ sive_etal.html.

[35] MIT Office of the Provost/Institutional Research. M.I.T. numbers: Postdoctoral scholars by international status and ethnicity. Online: http://web.mit.edu/fnl/volume/301/ numbers1.html.

[36] MIT Postdoctoral Association. Postdoc hiring and recruitment at MIT. Online: https://pda.mit.edu/resources/ diversity/postdoc-hiring-at-mit/.

[37] Denson, N. \& Chang, M. J. Racial diversity matters: The impact of diversity-related student engagement and institutional context. American educational research journal 46, 322-353 (2009). Online: https: / /www.jstor.org/stable/ 40284795 .

[38] Israel, E. \& Batalova, J. International students in the United States (2021). Online: https:// www.migrationpolicy.org/article/internationalstudents-united-states-2020.

[39] McKivigan, J. M. Effect of federal policy changes on international students pursuing higher education studies in the United States. Higher Education Research 5, 60 (2020). Online: https://touroscholar.touro.edu/cgi/ viewcontent.cgi?article=1046\&context=chhs_pubs.

[40] Marbang, P., McKinzie, A. E., Eller, J. \& Leggett, I. F. International students' experiences with changing policy: A qualitative study from middle Tennessee. Journal of Interdisciplinary Studies in Education 9, 301-329 (2020). Online: https://files.eric.ed.gov/fulltext/ EJ1294618.pdf.

[41] Business Roundtable. State of immigration how the United States stacks up in the global talent competition. Business Roundtable. Online: https: //s3.amazonaws.com/brt.org/ BRT-immigrationreport-2.pdf.

[42] Pierce, S. \& Bolter, J. Dismantling and reconstructing the U.S. immigration system. Migration Policy Institute. Online: https://www.migrationpolicy.org/sites/default/ files/publications/MPI_US-Immigration-TrumpPresidency-Final.pdf.

[43] Chiose, S. Canadian universities see surge of international students. The Globe and Mail. Online: https://www.theglobeandmail.com/news/national/ education/international-admissions-tocanadian-universities-see-significantincrease/article34984977/.

[44] Institute of International Education. About open doors. Online: https: //opendoorsdata.org/about/.

[45] Australian Government Department of Home Affairs. Student visa program. Online: https://data.gov.au/data/ dataset/student-visas.

[46] Universities UK. Export revenue: Effect of immigration rule changes. Tech. Rep. Online: https:// www.universitiesuk.ac.uk/news/Documents/Losteducation-export-value.pdf.

[47] BBC News. Immigration status: Ministers reverse May-era student visa rules. Online: https://www.bbc.com/news/uk49655719.

[48] U.K. Home Office. Student visitors. Online: https: / / data.gov.uk/dataset/3050223e-8596-44af-a8d4df062aa560bf/student-visitors.

[49] Higher Education Student Statistics. Higher education student statistics: UK, 2018/19, statistical bulletin SB255. Online: https: / / www.hesa.ac.uk/news/16-01-2020/sb255higher-education-student-statistics.

[50] Statistics Canada. Online: https://www.statcan.gc.ca/ eng/start. 
[51] Institute of International Education. Project Atlas infographics and data. Online: https://www.iie.org/en/Researchand-Insights/Project-Atlas/Explore-Data.

[52] Quillian, L. Prejudice as a response to perceived group threat: Population composition and anti-immigrant and racial prejudice in europe. American Sociological Review 586-611 (1995). Online: https: //www.jstor.org/stable/2096296.

[53] Schneider, S. L. Anti-immigrant attitudes in Europe: Outgroup size and perceived ethnic threat. European Sociological Review 24, 53-67 (2008). Online: https://academic.oup.com/ esr/article-abstract/24/1/53/463221.

[54] Küpper, B., Wolf, C. \& Zick, A. Social status and anti-immigrant attitudes in Europe: An examination from the perspective of social dominance theory. International Journal of Conflict and Violence (IJCV) 4, 205-219 (2010). Online: https: // www.ijcv.org/index.php/ijcv/article/view/2826.

[55] National Science Board. Science and engineering indicators; foreign-born students and workers in the U.S. science and engineering enterprise (2020). Online: https:// www.nsf.gov/nsb/sei/one-pagers/Foreign-Born.pdf.

[56] Stephan, P. E. \& Levin, S. G. Exceptional contributions to US science by the foreign-born and foreign-educated. Population Research and Policy Review 20, 59-79 (2001).

[57] Hunt, J. Which immigrants are most innovative and entrepreneurial? Distinctions by entry visa. Journal of Labor Economics 29, 417-457 (2011).

[58] National Foundation for American Policy. The importance of international students to American science and engineering. Online: https://nfap.com/wp-content/uploads/ 2017/10/The-Importance-of-InternationalStudents.NFAP-Policy-Brief.october-20171.pdf.

[59] Sargent Jr., J. F. The US science and engineering workforce: Recent, current, and projected employment, wages, and unemployment. Online: https:// crsreports.congress.gov/product/pdf/R/R43061.

[60] Widener, A. Science in the US is built on immigrants. Will they keep coming? Chemical Engineering News 97, 34-40 (2019).

[61] American Immigration Council. Foreign-born STEM workers in the United States. Online: https: //www.americanimmigrationcouncil.org/ sites/default/files/research/foreignborn_stem_workers_in_the_united_states_final.pdf.

[62] Jones, C. I. Sources of us economic growth in a world of ideas. American Economic Review 92, 220-239 (2002).

[63] Lewis, E. \& Peri, G. Immigration and the economy of cities and regions. In Handbook of regional and urban economics, vol. 5, 625-685 (Elsevier, 2015).

[64] Zavodny, M. The impact on U.S. men and women in STEM fields of increases in international students. National Foundation for American Policy. Online: https://nfap.com/wp-content/uploads/2021/04/ International-Students-and-STEM.NFAP-PolicyBrief.April-2021.pdf.

[65] Kerr, S. P., Kerr, W., Özden, Ç. \& Parsons, C. Global talent flows. Journal of Economic Perspectives 30, 83-106 (2016).

[66] National Academies of Sciences, Engineering, and Medicine and others. The economic and fiscal consequences of immigration (National Academies Press, 2017). Online: https: / / www.nap.edu/catalog/23550/the-economicand-fiscal-consequences-of-immigration.

[67] Chellaraj, G., Maskus, K. E. \& Mattoo, A. The contribution of international graduate students to US innovation. Review of International Economics 16, 444-462 (2008).

[68] Peri, G., Shih, K. \& Sparber, C. STEM workers, H-1B visas, and productivity in US cities. Journal of Labor Economics 33, S225-S255 (2015).

[69] Congressional Budget Office. The economic impact of S.744, the border security, economic opportunity, and immigration modernization act Press release accompanying the full
CBO report. Online: https: / / www.cbo.gov/publication/ 44346.

[70] Congressional Budget Office. The economic impact of S. 744, the border security, economic opportunity, and immigration modernization act Online: https://www.cbo.gov/sites/ default/files/cbofiles/attachments/44346Immigration.pdf.

[71] U.S. International Trade Administration. Education service exports. Online: https://www.trade.gov/educationservice-exports.

[72] Mitchell, M., Leachman, M. \& Masterson, K. A lost decade in higher education funding: State cuts have driven up tuition and reduced quality. Center on Budget and Policy Priorities. Online: https://www.cbpp.org/research/state-budget-andtax/a-lost-decade-in-higher-education-funding.

[73] Laderman, S. \& Weeden, D. SHEF: State higher education finance, FY 2019 (2020). Online: https: //shef.sheeo.org/wp-content/uploads/2020/04/ SHEEO SHEF FY19 Report.pdf.

[74] Ruiz, N. G. \& Radford, J. New foreign student enrollment at US colleges and universities doubled since great recession. Pew Research Center. November 20 (2017). Online: https: //www.pewresearch.org/fact-tank/2017/11/20/newus-foreign-student-enrollment-doubled-sincegreat-recession/.

[75] Bound, J., Braga, B., Khanna, G. \& Turner, S. A passage to America: University funding and international students. National Bureau of Economic Research (2016). Online: https:// www.nber.org/papers/w22981.

[76] Sacramento Business Journal. UC Davis plans growth spurt despite cuts. Online: https://www.bizjournals.com/ sacramento/news/2011/09/21/ucd-plans-growthspurt-despite-cuts.html.

[77] Golden, C. UCD plan: Add 5,000 students, 300 faculty in five years. Davis Enterprise Online: https: //www.davisenterprise.com/news/local/ucd/ucdplan-add-5000-students-300-faculty-in-fiveyears/.

[78] Katehi, L. P. B. News about the 2020 initiative. UC Davis Chancellor's Message. Online: https: / / www.ucdavis.edu/ sites/default/files/upload/files/chancellormessage-2020-initiative.pdf.

[79] Alvarez, F. \& Douglas, C. M. Cutting class: Uncertainty around international students puts colleges in limbo. Sacramento Business Journal. Online: https: / /www.biz journals.com/ sacramento/news/2020/08/13/internationalstudents-budget-crisis-for-colleges.html.

[80] Easley, J. A. Admission at UC Davis more selective for fall 2009. UC Davis Press Release. Online: https://www.ucdavis.edu/news/admission-ucdavis-more-selective-fall-2009.

[81] Common data set 2018-2019. University of California, Davis. Online: https://aggiedata.ucdavis.edu/sites/ g/files/dgvnsk1841/files/files/page/20182019CDS_1.pdf.

[82] Joint report of the 2020 task forces. University of California, Davis. Online: https://www.ucdavis.edu/sites/ default/files/upload/files/joint-report-2020task-forces.pdf.

[83] Hexter, R. J. 2020 initiative update. University of California, Davis. Online: https://www.ucdavis.edu/sites/ default/files/upload/files/2020-initiativeupdate.pdf.

[84] NAFSA international student economic value tool. Online: https://www.nafsa.org/policy-and-advocacy/ policy-resources/nafsa-international-studenteconomic-value-tool-v2.

[85] Institute of International Education. Open doors annual release. Online: https://opendoorsdata.org/annualrelease/. 
[86] Mitchell, T. Letter to congress on COVID supplemental funding. Tech. Rep., American Council on Education. Online: https://www.acenet.edu/Documents/LetterCongress-October-COVID-Supplemental-101920.pdf.

[87] New America. The impact of COVID-19 on state higher education budgets. Online: https: / / www.newamerica.org/ education-policy/reports/state-budgetcuts/introduction/.

[88] Institute of International Education. Fall international enrollments snapshot reports. Online: https:// www.iie.org/Research-and-Insights/OpenDoors/Fall-International-Enrollments-SnapshotReports.

[89] Redden, E. International student numbers decline. Inside Higher Ed. Online: https://www.insidehighered.com/ news/2020/11/16/survey-new-internationalenrollments-drop-43-percent-fall.

[90] McPherson, M. P. How the Biden administration can make the U.S. a top destination for international students. Forbes .

[91] Knight, W. The US needs more foreign artificial intelligence know-how. Wired. Online: https://www.wired.com/ story/us-needs-more-foreign-artificialintelligence-know-how/.

[92] Zwetsloot, R., Dunham, J., Arnold, Z. \& Huang, T. Keeping top Al talent in the United States: Findings and policy options for international graduate student retention (2019).

[93] Roach, M. \& Skrentny, J. Rethinking immigration policies for STEM doctorates. Science 371 (2021). Online: https: //science.sciencemag.org/content/371/6527/350.

[94] Roach, M. \& Skrentny, J. Why foreign STEM PhDs are unlikely to work for us technology startups. Proceedings of the National Academy of Sciences 116, 16805-16810 (2019). Online: https://www.pnas.org/content/pnas/ 116/34/16805.full.pdf.

[95] Anderson, S. Letting international students start businesses is a win-win for the United States. International Educator 21, 4 (2012).

[96] Han, X. \& Appelbaum, R. Stay or go home? International STEM students in the United States are up for grabs after graduation (2016). Online: https://papers.ssrn.com/ sol3/papers.cfm?abstract_id=2859877.

[97] Nowrasteh, A. Boost highly skilled immigration. In Cato Institute Online Forum. Online: https: //www.cato.org/cato-online-forum/boosthighly-skilled-immigration?queryID= bbf9584fa72c70bbc25e1c8e0f24d21f.

[98] Tech Nation. Tech Nation visa report 2020. Tech. Rep. (2020). Online: https://technation.io/tech-nationvisa-report-2020/.

[99] Rose, J. Canada wins, U.S. loses in global fight for high-tech workers. NPR. Online: https://www.npr.org/2020/01/ 27/799402801/canada-wins-u-s-loses-in-globalfight-for-high-tech-workers.

[100] Thompson, C. Tech workers are living the American dream-in Canada. Wired. Online: https://www.wired.com/story/ immigrant-tech-workers-american-dream-canada/.

[101] National Security Commission on Artificial Intelligence. Final report (2021). 